\title{
The Practical Research of Implementing Family Affection Education in Higher Education
}

\author{
Lu Dan*, Zhang Junjie \\ Yunnan University of Finance and Economics, Kunming, P.R. China 650221 \\ (E-mail:yufejennyludan@126.com, 64306626@qq.com)
}

\begin{abstract}
Because of the social transformation, diversification of value, internet and other reasons, there are various problems of lacking of affection among college students at present. This paper integrates the practical college education to analyze the objectives and process of the implementation of affection education in high education, which aims to point out the vital functions of affection education for developing sound mind and all-round personality among college students. The paper also puts forward some methods and suggests for the implementation of affection education in high education.
\end{abstract}

Keywords: Higher Education, College Students, Affection Education, Practical Research.

\section{Introduction}

There is an old saying:

Filial good for the first 100 , respecting the aged and cherishing the young are the traditional virtue of Chinese. Family affection is the compulsory course for most of Chinese. Whereas, due to the factors such as social transformation, diversification of value and internet, which cause the lack of affection among college students and publics, it was painful for such phenomenon. Therefore, people have to study how to promote the affection education under the current education system. For the high education, it not only means cultivating students' abilities, but also establishing their characters, which means to guide students to build sound personality and make them behave well that should be the focus of the higher education. Presently, it is significant to develop the family affection education among college students.

Some psychological researchers indicated that Emotional Quotient (EQ) was the key factor to determine a person's success. EQ is occupied $80 \%$, and Intelligent Quotient (IQ) only accounts for $20 \%$ of personal successes. While family affection is the important embodiment of EQ, it is the name of kind of emotions including affections between parents and children, siblings and etc.

Family Affection Experiential Education means making students empathize with others, and learn understanding, caring and respecting family through involving in the various activities in the family, school and the society. Thus, improving and enhancing the relationship around family members will help cultivate the gratitude and filial consciousness of students, and achieve a gratitude humanistic education.

\section{The Necessity of Developing the Affection Experiential Education}

Affection Experiential Education is an important content of college students' ideological, moral and quality education. It would be regarded as the foundation of all the educations. Family affection experiential teaching activities would promote the development of students' quality in an all-round way, build the college's spirit, teaching and learning styles, and encourage the establishment of a harmonious culture in the campus. Developing family affection experience teaching is based on the considerations of enhancing the Chinese traditional virtues, family 
ethics education, and spiritual civilization developments. Meanwhile it would be an attempt of exploring the effectiveness of ideological education, and creating a new situation of moral education.

First, developing family affection experiential education is beneficial to promote the comprehensive skills of college students. Through affection experiential education the cultivate students' caring, understanding, respecting, confidence, self-esteem, self-improvement, self-discipline, and hard working. At the same time, it can guide students to treat ourselves kindly, gain respects from others, improve interpersonal relationships, conduct self- education, and help students to build up the lofty ideals and beliefs. Meanwhile it can also educate students the concepts of achieving the ideal personality target by hard working and dedication. Students analyze their current situation based on the affection experience, so as to stimulate their kindheartedness, thankfulness, empathy, and sense of social responsibility.

Second, developing affection experiential education is beneficial to establish human nature, raise a good mindset as thanksgiving, honesty and sharing for students, and make them to understand the importance of affection and the hardships of the elder generations, cherish the sincere and unselfish loves in the life from parents, educate tolerant and understandable, so as to cultivate them to return to other people and society. The affection experience education will make an open communication through increasing opportunities of gathering around family. Therefore, students will learn to stand on other people's side, think by listening to other people, eliminate diaphragm between each other, and share their joys and sorrows.

Third, developing affection experiential education helps to promote a harmonious campus via establishing fine school spirit, teaching and learning styles. A grateful heart can be deemed as morality, responsibility, and also a grain of seed of harmony, by doing so, students will reduce complaint and confrontation, bring much more friendships and joys, honor and respect to their parents and teachers, pose ambitions, study hard, and enhance a comprehensive ability to adapt to the workplace. The family affection is the adhesives of emotion. It can effectively promote the harmonious interpersonal relationship with people's courtesy, honesty, and concerns, thus achieving the aim of building the harmonious campus.

Four, developing family affection experiential education is based on developing the Chinese traditional virtue, emphasizing family ethical education, and practicing spiritual civilization. Filial piety is normally conducted as the Chinese traditional moral standard for the generations in thousands years with its connotations of treating parents kindly and respecting parents. It is worth mentioning that filial piety is completely mixed with social moral though taking the essence and discarding the dross which is worth to widely advocate. Each family is a cell of society, so it means if each family would follow the moral standard of filial piety, it will form a stable relationship in the family and ultimately promote the steady and development of whole society.

Five, developing family affection experiential education is an attempt of exploring an effectiveness of ideological education, and starting of new situation of moral education. Patriotism and moral education are the foundation of ideological education and the activities of family affection experiential education is a breakthrough point for practicing it. The college will inspire the students respecting, sharing and showing piety to the parents through the activities, so 
as to achieve the trinity of "educates students, benefits the country, and cheers the family finally".

\section{The Implementation of Affection Experiential Education}

Students cannot be forced to have filial piety by a rigid action, but have to move them and make the filial piety as a natural behavior, so it would be defined as achieve real filial piety through putting thoughts into action. To realize the systematic and long-term teaching style of affection experiential education, we should integrate the real situation of college students and strictly follow the pattern of combining family, school and social education.

\subsection{Affection Experiential Education} Implementation in Family

In the family, parents are the witnesses of affection experiential education, their attitude to their parents and children, so the way of communicating with friends and relatives will influence on students directly. The "Manchester Investigation Report" from British stated "the key success factors of education are in family, the importance of family factors almost double the factors of community and school." Therefore, the family is the most ideal place of affection experience learning and parents are the best teachers.

First, strengthening the communication between students and parents. Currently, parents still stay on emphasizing IQ but neglecting EQ education, so it will result outstanding talents with an extremely cold heart. According to the survey, parents are the direct influential factor of causing lack of affection for students in such education concept. Therefore, parents should have introspection, and the teacher should contact with parents about students' affection situation, and provide guidance to parents about family affection education. The colleges can also make some family education material or use the network platform to offer consults.

Second, building family information file will help understand details of the parents, such as their working time, income, expenses, housework, and etc. Making students respect, concern, comfort, trust their parents by understanding parents' hard working, learning to think from the point of view of the parents, communicating with parents often, and enhancing the sense of responsibility to the family.

Third, setting various family experience activities homework for students. Requesting student to participate in the activities of family, for instance, giving parents hug, saying "I love you" to them every day, talking to them, taking some housework, and then recording all the activities into the experience report, requesting parents to evaluate students' performance according to the reports. This is a platform for parent to communicate with students, to wake up the students' family awareness, rouse the close affection of the parent's education, and make more harmonious relationship between parents and students through interactive experience.

\subsection{Affection Experiential Education} Implementation in School

College should create an atmosphere of affection education, build the filial piety, love campus environment, and influence students by family affection experience. First, organizing activity of exploring family affection. This is a preparation work of affection experiential education. In this stage, students will anatomize their present affection, which will remind students to self-reflect introspection through the questionnaire investigation, interview with parents and self-reflection form. At the same 
time, it can make teacher to know the students awareness of affection.

Second, launching various affection experience education activities. Lectures should combine practice with theory, and the teaching activities should be implemented through introduce the theory theme activities, case study, situation teaching, movie appreciation, discussions to share the connotation and meaning of affection experiences with students. Family affection experiential education has more space in activities, because there is about a third of the time for study, a third of the time for sleeping, a third of the time for all kinds of activities during in students' university life time. Colleges can design related activities in the particular time, such as contribution to the society by working in NGO, and through it the affection will warm every corner of the whole society. Making a public view of affection by publicities, setting up the model of filial piety will help students to feel family love, understand affection, and be grateful, honesty and sharing.

\subsection{Affection Experiential Learning Implementation in Society}

The family, school and society should take responsibilities of affection experiential education, through enhancing communication in these three parties to intensify and publicity the affection concepts to achieve the real affection experiential education, and establish a common atmosphere of affection in society. The participation of social organizations will help to expand family activity into a wider group, such as the TV programs, video, reference books, etc. Such activities are more orderly, and have greater social influences. There are some theme training programs which request students and parents to join together under the guidance of trainer to complete role play, emotional training, games and many kinds of interactive activities, makes students and family together have a trip of emotions and family affection.

\section{Evaluation of Affection Experiential Education}

\section{Achievement}

The evaluation mechanism has significance on students' affection awareness besides changing the self-concepts. Evaluation methods include selfassessment and assessment by others. Selfexamination will be followed by each learning activity, and it is an essential process of directing students to focus on learning targets. Furthermore, the concepts of affection of students' own experiences will convert into a conscientious. During the learning activities, students will be required to analyze the affection between themselves and their families, performance on the experiential process, knowledge of solving problems in interpersonal relations, even the deficiencies and improvements in the future, and etc. During this process, students can build the awareness of their own affection situation and motive themselves. There are many formations of assessments by others that would be the professional experts' assessment and family assessment. The feedbacks of others will support students to cognize themselves.

\section{References}

(1) Huang Tianzhong (2009).Career PlanningExperiential Learning. Beijing: Higher Education Press.

(2) Yin Yingxia (2007). Cultivation of college students' responsibility and "thankfulness" education. GuangDong University of Technology Press. 
(3) Zhao Jianlin (2007)The Reflect On Emphasizing College Students Family Affection Education. Shanxi Agricultural University Press. 